Neues aus der Forschung

Redaktion: Josef Gulden

\section{Prenylierung von Onkoproteinen Besser zwei Enzyme hemmen als nur eines}

Die Onkoproteine RAS und RHO, die die Entstehung und Metastasierung vieler Tumoren auslösen können, werden erst aktiv, wenn sie an die Innenseite der Zellmembran andocken. Dazu müssen sie mit einem Isoprenyl-Lipidrest versehen werden. Diesen Prozess bewerkstelligen die Enzyme Farnesyltransferase (FTase) und Geranylgeranyltransferase I (GGTase I).

Inhibitoren der FTase sind mit mäßigem Erfolg unter anderem bei der akuten myeloischen Leukämie getestet worden. Deshalb wollten schwedische, chinesische und US-amerikanische Kollegen wissen, ob es wirksamer ist, beide Enzyme gleichzeitig auszuschalten.

Zumindest in einem Tiermodell ließ sich das bestätigen: Wurde das Gen für die FTase in Mäu- sen mit KRAS-induzierten Lungentumoren ausgeschaltet, hemmte dies das Tumorwachstum und verlängerte die Überlebenszeiten der Tiere, ähnlich wie das vorher auch schon für die Inaktivierung der GGTase I gezeigt worden war. Schalteten die Wissenschaftler beide Gene aus, war dieser Effekt noch viel ausgeprägter, ohne dass es zu einer nennenswerten Lungentoxizität gekommen wäre. Die simultane Hemmung dieser beiden Enzyme könnte also erheblichen therapeutischen Nutzen bringen, hoffen die Autoren.

Liu M et al. Targeting the protein prenyltransferases efficiently reduces tumor development in mice with K-RAS-induced lung cancer. Proc Natl Acad Sci USA 2010;107:6471-6.

\title{
Optische Kohärenz-Tomografie Nicht invasive Darstellung von Lymphknotenmetastasen
}

Ob Lymphknoten von Krebs befallen sind, bestimmt bislang der Pathologe. Möglicherweise
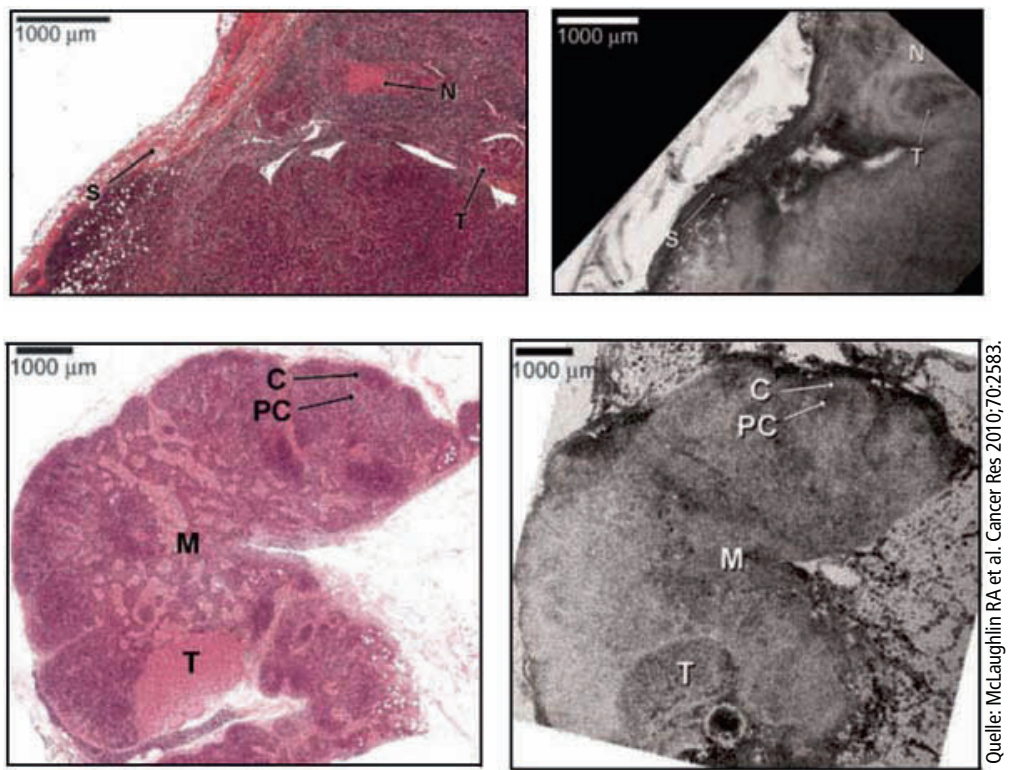

Abbildung 1. Lymphknoten in der Histopathologie (Hämatoxylin-Eosin, links) und OCT (rechts). T: diskrete Metastasen, S: Stroma, N: nekrotische metastatische Ablagerung, C: Kortex, PC: Parakortex, M: Medulla. wird dies irgendwann nicht invasiv machbar sein, sodass man viele Lymphadenektomien vermeiden könnte: Australische Mediziningenieure und Chirurgen benutzen die optische KohärenzTomografie (OCT). Durch diese Methode kann man mit Licht im nahen Infrarot-Bereich mikroskopische Gewebedetails in situ in hoher Auflösung darstellen. In einer Pilotstudie untersuchten die Forscher ex vivo gesunde sowie mit Mammakarzinomen infiltrierte Lymphknoten. Sie fanden eine gute Korrelation mit der Histopathologie, was sowohl die Darstellung von Fett, Blutgefäßen und Keimzentren als auch von Stroma und malignem Gewebe anging (Abb. 1). Die In-vivo-Anwendung birgt jedoch noch technische Herausforderungen, weil die Eindringtiefe der optischen Methode nur bei wenigen Millimetern liegt. Es gibt aber bereits miniaturisierte OCT-Sonden, die in einer Art Kanüle mit dem Lymphgewebe in direkten Kontakt gebracht werden könnten.

McLaughlin RA et al. Imaging of human lymph nodes using optical coherence tomography: Potential for staging cancer. Cancer Res 2010;70:2579-84. 